\title{
Isotope Separations Section Progress Report for \\ Quarter Ending June 30, 1976
}

\author{
E. Newman \\ W. A. Bell, Jr. \\ W. C. Davis \\ H. R. Gwinn
}

\section{OAK RIDGE NATIONAL LABORATORY}




\section{DISCLAIMER}

This report was prepared as an account of work sponsored by an agency of the United States Government. Neither the United States Government nor any agency Thereof, nor any of their employees, makes any warranty, express or implied, or assumes any legal liability or responsibility for the accuracy, completeness, or usefulness of any information, apparatus, product, or process disclosed, or represents that its use would not infringe privately owned rights. Reference herein to any specific commercial product, process, or service by trade name, trademark, manufacturer, or otherwise does not necessarily constitute or imply its endorsement, recommendation, or favoring by the United States Government or any agency thereof. The views and opinions of authors expressed herein do not necessarily state or reflect those of the United States Government or any agency thereof. 


\section{DISCLAIMER}

Portions of this document may be illegible in electronic image products. Images are produced from the best available original document. 
Printed in the United States of America. Available from National Technical Information Service

U.S. Department of Commerce

5285 Port Royal Road, Springfield, Virginia 22161

Price: Printed Copy $\$ 3.50$; Microfiche $\$ 2.25$

This report was prepared as an account of work sponsored by the United States Government. Neither the United States nor the Energy Research and Development Administration/United States Nuclear Regulatory Commission, nor any of their employees, nor any of their contractors, subcontractors, or their employees, makes any warranty, express or implied, or assumes any legal liability or responsibility for the accuracy, completeness or usefulness of any information, apparatus, product or process disclosed, or represents that its use would not infringe privately owned rights. 
Contract No. W-7405-eng-26

CHEMICAL TECHNOLOGY DIVISION

\section{ISOTOPE SEPARATIONS SECTION PROGRESS REPORT}

FOR QUARTER ENDING JUNE 30, 1976

E. Newman

Compiled from contributions by:

W. A. Bel1, Jr.

W. C. Davis

H. R. Gwinn

Date Published: October 1976

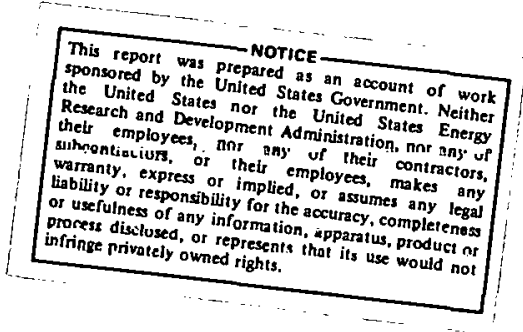

NOTICE This document contains information of a preliminary nature and was prepared primarily for internal use at the Oak Ridge National Laburatury. Ii ls subjoul lis idvision or corraction and thoroforo dooo not represent a final report.

OAK RIDGE NATIONAL LABORATORY

Oak Ridge, Tennessee 37830

operated by

UNION CARBIDE CORPORATION

for the

ENERGY RESEARCH AND DEVELOPMENT ADMINISTRATION 
THIS PAGE

\section{WAS INTENTIONALLY \\ LEFT BLANK}


CONTENTS

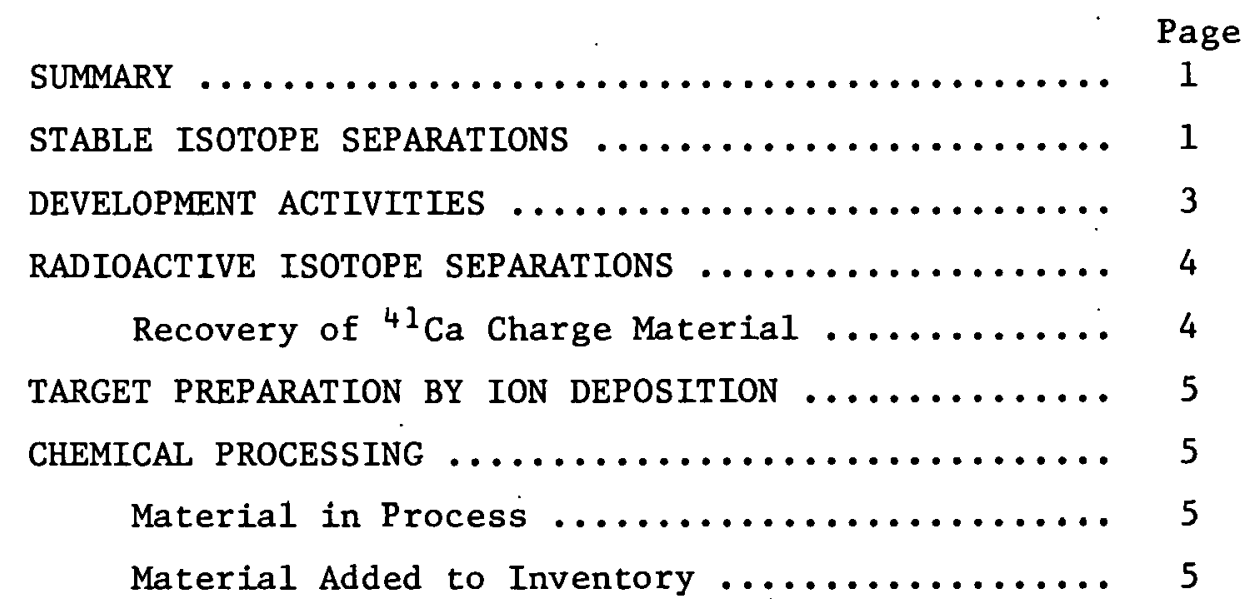


ISOTOPE SEPARATIONS SECTION PROGRESS REPORT

FOR QUARTER ENDING JUNE 30, 1976

\section{E. Newman}

\section{SUMMARY}

The activities of the Isotope Separations Section of the Chemical Technology Division are described for the quarter ending June 30, 1976. Included is the status of the current electromagnetic separation of the isotopes of iron, nickel, and selenium. In-process research and development activities relating to current separations are described and assessed. The preparation of thin isotopically enriched palladium targets by ion deposition in the $180^{\circ}$-sector isotope separator using chlorine trifluoride as a halogenating agent has been achieved. Summary tabulations are given of elements chemically processed and new lots of isotopes released, or available, to inventory.

\section{STABLE ISOTOPE SEPARATIONS}

Isotopic separations of iron, nickel, and selenium were in progress in 24 beta-type electromagnetic isotope separators at the end of the reporting period. These separations, all of which were initiated during the quarter, were conducted on a 5-day, 24-hr basis. The objective of the iron, nickel, and selenium separations was to collect $\sim 30 \mathrm{~g}$ of $>93 \%$ ${ }^{57} \mathrm{Fe},{ }^{7}, 30 \mathrm{~g}$ of $95 \%{ }^{62} \mathrm{Ni}$ and $\sim 2 \mathrm{~g}$ of $>75 \%{ }^{74} \mathrm{Se}$, primarily for replenishment of the Sales inventory. The nickel separation, which is being made with double arc equipment, is expected to terminate early in July, while the iron and selenium separations are scheduled to continue throughout the next quarter. Double arc equipment is also being employed in two of the eight separators allocated to selenium in order to increase the collection rate of ${ }^{74} \mathrm{Se}$.

The separations of chlorine, germanium, and tin were completed early in the quarter, and the resulting products are currently undergoing final recovery and chemical purification. The actual quantity and isotopic purity of the ${ }^{37} \mathrm{Cl}$, together with the estimated recovery weights of the remaining nuclides, are given in Table 1. 
Table 1. Operations status for the period April-June 1976

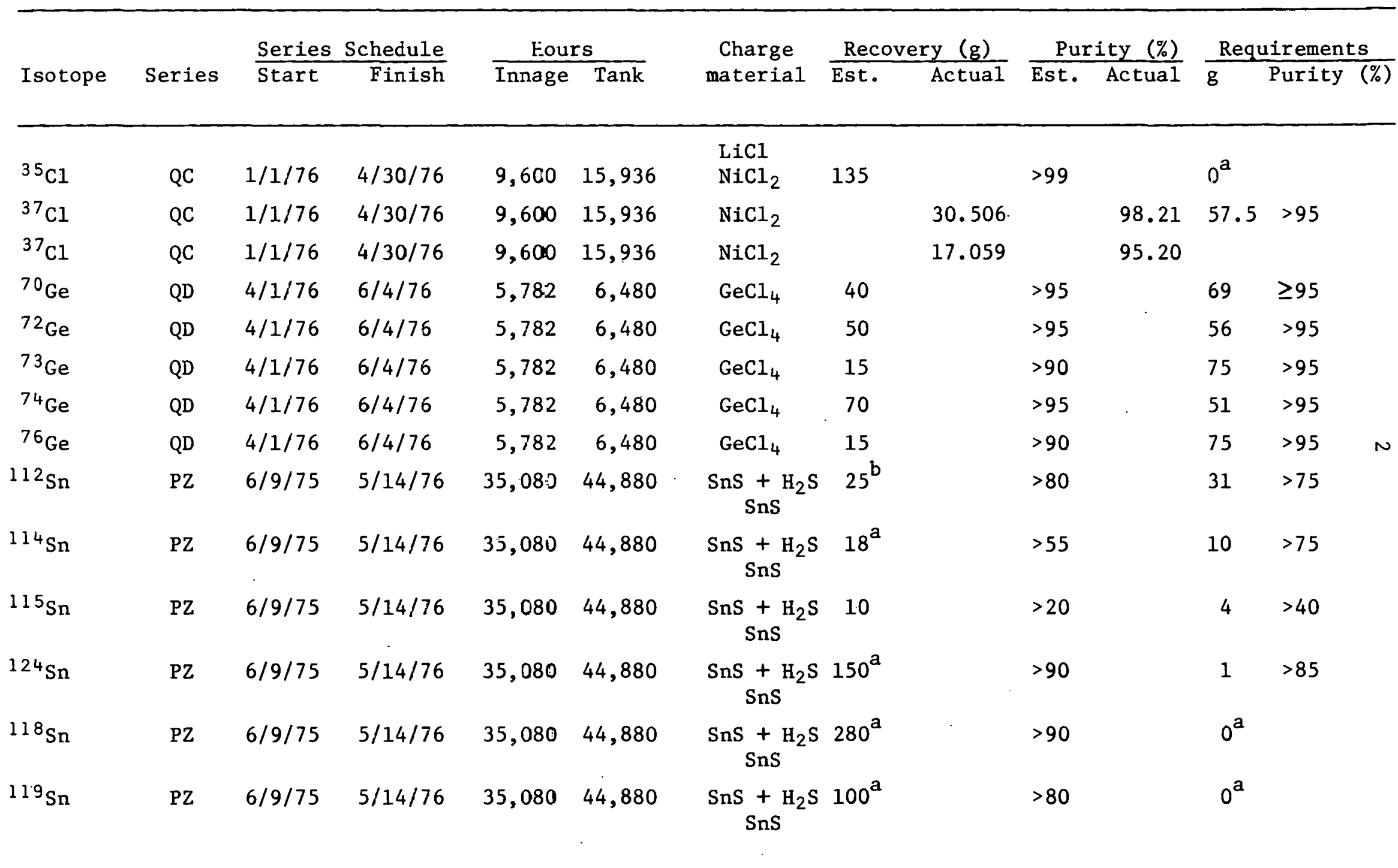

a Not to be recovered at this time.

${ }^{b} \mathrm{~A}$ total of $5.155 \mathrm{~g}$ of this material was irventoried on October 22, 1975, to provide material for Sales. 


\section{DEVELOPMENT ACTIVITIES}

In preparing for a new series for the enrichment of selenium and iron, past separations data were analyzed in an effort to increase the overall performance. Equipment design and operating parameters were chosen to emphasize isotopic enhancement.

A method of providing continuous peak-to-valley current readings was designed and installed in one iron receiver. The normal method of obtaining the readings is to periodically move the beam out of the monitor pocket and record the valley current between two adjacent mass peaks. Continuous peak-to-valley monitoring can eliminate this need for beam movement and be used as an additional diagnostic tool to maintain optimum beam focusing and hence higher isotopic purity. Two probes were installed in the receiver. The first was an exposed strip located at the mass 55 position; the second was a pocket located at the mass 53.5 position. The response of the mass 55 probe was much more sensitive to changes in beam conditions than was the mass 53.5 probe, however, the readings from either of these probes did not correlate well with the normal peak-to-valley ratios. This apparent discrepancy may be due to the isotopic mass abundance distribution for irọn.

The observed peak-to-valley ratio was less than that calculated to obtain the required isotopic purity at the start of the series, but exceeded it for most of the remaining time. As the assay of the runs becomes available, the correlation coefficient between the peak-to-valley ratios and the isotopic contamination will be calculated to assess the sensitivity of the method.

The ion current monitored in collector pockets in the iron series is averaging 10 to $15 \%$ lower than that anticipated. The efforts to remedy this situation have not yet been successful. Changes that were introduced include the repositioning of the arc ribbon to the most forward position in the arc chamber, $\mathrm{J}_{0}$. In addition, the angular acceptance of the receiver to the incoming beam was increased by $40 \%$ (from $+6^{\circ},-6^{\circ}$ to $+6^{\circ}$, $-11^{\circ}$ ) without either an improved ion output or a deterioration of beam quality. We had expected one, or both, of these effects. 
The feed for this separation is $\mathrm{FeCl}_{2}$, which was purchased and specially fused for a prior separation. The feed is assumed to be of good quality since it has been stored in a sealed plastic container and the moisture content does not present a major problem. However, the charge consumption rate is lower than before and is limited by the early appearance of drain problems in the ion source operation. At present, change to a new batch of feed appears to be the only obvious approach left in raising the ion output to past levels.

\section{RADIOACTIVE ISOTOPE SEPARATIONS}

\section{Recovery of ${ }^{41} \mathrm{Ca}$ Charge Material}

$\mathrm{A}^{41} \mathrm{Ca}$ enrichment program was completed in one electromagnetic isotope separator in the radioactively contained area during September 1975 . However, the unresolved charge material, which was involved in the second cycling through the separator, was not removed from the separator until March 1976. Chemical recovery was subsequently delayed until early this quarter. This material, originally containing $1.53 \%{ }^{41} \mathrm{Ca}$, was produced by a three-year irradiation of enriched ${ }^{40} \mathrm{Ca}$ in the High Flux Isotopes Reactor. The recovered product is potentially a valuable sample for research and/or future ${ }^{41} \mathrm{Ca}$ enrichment programs.

The rocovery of the unresulved calclum was accomplished by stripping all metallic components with hot, dilute nitric acid. Graphite components were first leached in nitric acid and then consumed by ignition in oxygen. The calcium extracts were combined and subsequently purified through chemical recovery steps including electrolysis, precipitation with oxalic acid, and precipitation with ammonium carbonate. The product, which consists of $\sim 1.33 \%{ }^{41} \mathrm{Ca}$, contains significant quantities of cadmium, lanthanum, and zinc and is considered impure as compared with inventory material. The known impurities, however, are not expected to compromise the value of the sample as future charge material. 


\section{TARGET PREPARATION BY ION DEPOSITION}

Isotopically enriched thin targets of ${ }^{102} \mathrm{Pd}$ and ${ }^{104} \mathrm{Pd}$ were prepared during the quarter in the $180^{\circ}$-sector isotope separator by the surface deposition method. Deposits of $50 \mu \mathrm{g} / \mathrm{cm}^{2}$ on $75-\mu \mathrm{g} / \mathrm{cm}^{2}$ carbon backings were made for each isotope. The ion beams, which were produced from the in situ reaction of chlorine trifluoride and palladium metal to produce the volatile $\mathrm{PdF}_{2}$, were decelerated from about $35 \mathrm{keV}$ to $\sim 200 \mathrm{eV}$ at the point of impact on the substrate. The isotopic purity of the deposited target was estimated to be $>99 \%$ in each case, and the initial feed was natural isotopic material. These targets were prepared for use in cuulumb excitation studies.

\section{CHEMICAL PROCESSING}

Material in Process

The following elements were in chemical processing during the quarter: chlorine, iron, germanium, nickel, selenium, tin, and ytterbium. Material Added to Inventory

Table 1 identifies the isotopic material that was released or made available to Sales during this report period; the appropriate separation data are also included. In addition to the two new lots of ${ }^{37} \mathrm{C} 1$ released to Sales, ten loan-returned samples were processed and returned to the Research Materials Collection for inventory. 
THIS PAGE

\section{WAS INTENTIONALLY LEFT BLANK}


INTERNAL DISTRIBUTION

ORNL/TM-5625

1. G. M. Banic

27. P. H. Stelson

2. W. A. Bell, Jr.

28. M. G. Stewart

3. K. B. Brown

29. J. G. Tracy

4. J. W. Cleland

5. T. F. Connolly

30. D. B. Trauger

6. F. L. Culler, Jr.

31. J. R. Weir

7. W. C. Davis

8. D. E. Ferguson

9. H. R. Gwinn

1.0. J, A, Harvey

11. J. E. Keeton

12. 0. L. Keller

13. E. Lamb

14. F. C. Maienschein

32. J. C. White

33. M. K. Wilkinson

34. R. G. Wymer

35. J. O. Younghanse

36. A. Zucker

37. W. K. Davis (consultant)

38. E. L. Gaden, Jr. (consultant)

39. C. H. Ice (consultant)

15-19. E. Newman

40. L. 0. Love (consultant)

20. F. G. Perey

41. R. B. Richards (consultant)

21. H. Postma

22. W. K. Prater

23. J. E. Ratledge

24. F. M. Scheitlin

25-26. K. A. Spainhour

42. Laboratory Records - RC

43-52. Laboratory Records Department

53. ORNL Patent Section

54-55. Central Research Library

56. Document Reference Section

\section{EXTERNAL DISTRIBUTION}

57. N. F. Barr, Office of General Manager, ERDA, Washington, DC 20545

58. R. C. Block, Rensselaer Polytechnic Institute, Troy, NY 12181

59. R. M. Brugger, Aerojet Nuclear Company, Idaho Falls, ID 83401

60. J. L. Burnett, Division of Physical Research, ERDA, Washington, DC 20545

61. R. E. Chrien, Brookhaven National Laboratory, Upton, NY 11973

62. J. T. Christy, ERDA-RL00, Richland, Washington 99352

63. G. A. Cowan, Los Alamos Scientific Laboratory, Los Alamos, NM 87545

64. B. J. Dropesky, Los Alamos Scientific Laboratory, Los Alamos, NM 87545

65. L. Friedman, Brookhaven National Laboratory, Upton, NY 11973

66. K. A. Gschneidner, Jr., Iowa State University, Metallurgy and Ceramics, Ames, IA 50011

67. M. E. Harris, Lawrence Livermore Laboratory, Livermore, CA 94550

68. R. W. Hoff, Lawrence Livermore Laboratory, Livermore, CA 94550

69. H. E. Jackson, Argonne National Laboratory, Argonne, IL 60439

70. J. A. Lenhard, Research and Technical Support Division, ERDA-ORO

71. R. H. Leonard, Florida State University, Nuclear Research Bldg. No. 51, Tallahassee, FL 32306

72. J. L. Lerner, Argonne National Laboratory, Chemistry Division, Argonne, IL 60439 
73. J. N. Maddox, Division of Biomedical and Environmental Research, ERDA, Washington, DC 20545

74. W. B. Mann, National Bureau of Standards, Washington, DC 20234

75. J. W. Meadows, Lawrence Livermore Laboratory, Livermore, CA 94550

76. M. C. Michel, Lawrence Berkeley Laboratory, Berkeley, CA 94720

77. R. A. Naumann, Princeton University, Chemical Sciences, Princeton, NJ 08540

78. H. W. Newson, Duke University, Physics Department, Durham, NC 27706

79, H. A. O'Brien, Los Alamos Scientific Laboratory, Los Alamos, NM 87545

80. G. L. Rogosa, Division of Physical Research, ERDA, Washington, DC 20545

81. B. C. Rusche, Savannah River Laboratory, Aiken, SC 29810

82. L. G. Stang, Brookhaven National Laboratory, Upton, NY 11973

83. W. L. Talbert, Jr., Iowa State University, Nuclear Science, Ames, IA 50011

84. G. Taplin, University of California, Los Angeles, CA 90024

85-89. D. H. Turno, Savannah River Laboratory, Aiken, SC 29810

90. M. Williams, Lawrence Livermore Laboratory, Livermore, CA 94550

91-117. Technical Information Center, ERDA-OR 